\title{
Organizational transformation as a determinant of corporate hospitality and its effect on corporate sustainability
}

\author{
Hamidah Nayati Utami, Bambang Eka Cahyana, Umar Nimran and \\ Mohammad Iqbal \\ Brawijaya University, Malang, Indonesia
}

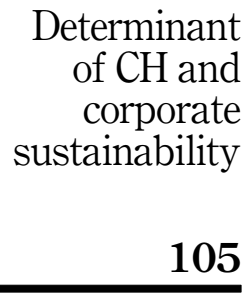

Received 26 April 2020 Revised 14 August 2020 Accepted 13 September 2020

\begin{abstract}
Purpose - This research was conducted with the aim of examining and explaining the effect of strategic leadership, corporate governance, organizational culture, business infrastructure and corporate alignment as determinants of corporate hospitality; testing and explaining the direct effects of corporate hospitality and corporate sustainability.

Design/methodology/approach - This research used a quantitative approach with a survey method. The research population was all subsidiaries, branches and departments in PT Pelindo 1 (Persero). The sample size in this research was $n=N=61$, which covered 5 subsidiaries, 17 branches and 39 directorates at PT Pelindo 1 (Persero). Data analysis was done with inferential statistics using WarpPLS analysis using the help of WarpPLS package computer programs.

Findings - There is a significant and positive direct effect between Strategic Leadership, Corporate Culture, Corporate Governance, Business Infrastructure and Corporate Alignment on Corporate Hospitality which means higher Strategic Leadership, Corporate Culture, Corporate Governance, Business Infrastructure and Corporate Alignment will result in a higher Corporate Hospitality. The analysis also shows that there is a significant and positive indirect effect between Strategic Leadership, Corporate Culture, Corporate Governance, Business Infrastructure and Corporate Alignment on Corporate Sustainability through Corporate Hospitality which means higher Strategic Leadership, Corporate Culture, Corporate Governance, Business Infrastructure and Corporate Alignment will lead to higher Corporate Sustainability through Corporate Hospitality.

Originality/value - The originality of this research can be proven from the lack of research on hospitality. Some other research on hospitality, mostly doing research at airports, hospitals and hotels. However, this research was conducted at the port, where company friendliness is a discipline that includes many marketing studies.
\end{abstract}

Keywords Sustainable management, Organizational transformation, Hospitality, Corporate sustainainability Paper type Research paper

\section{Introduction}

PT Pelabuhan Indonesia 1 Persero (Pelindo 1) is one of the ports in Indonesia which is located in outer islands which make it directly adjacent to the high sea and other countries. In dealing with market globalization, PT Pelindo 1 must improve itself by making changes from port operator company to integrated port and logistic service corporate. Integrated port and logistic service corporate in question include port operators, logistics providers and regional development. This is done to improve corporate performance and ensure corporate

(C) Hamidah Nayati Utami, Bambang Eka Cahyana, Umar Nimran and Mohammad Iqbal. Published in International Trade, Politics and Development. Published by Emerald Publishing Limited. This article is published under the Creative Commons Attribution (CC BY 4.0) license. Anyone may reproduce, distribute, translate and create derivative works of this article (for both commercial and non-commercial purposes), subject to full attribution to the original publication and authors. The full terms of this license may be seen at http://creativecommons.org/licences/by/4.0/legalcode

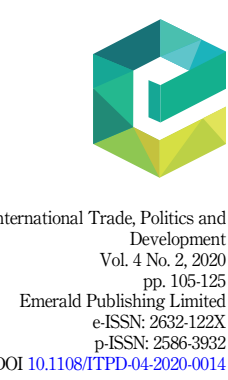


ITPD

4,2

106

sustainability. In other words, with these changes, PT Pelindo 1 is expected to win the competition in the era of market globalization.

As stated in the resource based view (RBV) theory, competitive advantage can be made if a business organization is successful in creating strategies based on resources that are difficult to duplicate by competitors (Barney, 1991). Such resources can take the form of "assets, abilities, organizational processes, corporate attributes, information, and knowledge which are controlled by the organization" (Barney, 1991, p. 101). To be a potential source of competitive advantage, the underlying resource package must be scarce, valuable, nonreplicable and cannot be substituted. In this case, this approach is relevant in the aspect of how business organizations have capability to effectively utilize resources. Furthermore, the RBV theory is a discussion that becomes a crucial point and a major determinant in the development of strategic management approaches. Thus, the context of strategic management becomes an interesting dialogue material for study in the process of growing and developing an organization.

Organizational transformation is one of the important studies in strategic context, especially in developing competitive advantage. The organizational transformation context described by Porras and Silvers (1991) begin with a condition of organizational change triggered by relevant environmental shifts that are felt by the organization, leading to intentionally generated responses. The intentional responses are the basis for the planned organizational change, which consists of four identified and interrelated components, namely: (1) change intervention, (2) important variables of organizational goals, (3) individuals as members of their organizations and on-job behaviors that produce change and (4) organizational impacts (Porras and Silvers, 1991). In the context of organizational transformation, there are several crucial aspects that can affect the achievement of the impacts expected by the organization. The crucial aspects include: strategic leadership, corporate/organizational culture, corporate governance and business infrastructure.

Leader strategies reflect the mindset of the times and become important, especially being a problem for the evolution of sustainable governance applications. Therefore, leaders are individuals who have the ability to influence other individuals and groups to be able to work together to achieve their intended goals. One type of leadership context that an organization wants to achieve is strategic leadership. Strategic leadership refers to the potential of a manager to express a strategic vision for a company, or part of a company and to motivate and convince others to obtain that vision. Strategic leadership can also be interpreted as utilizing strategies in employee management. This aspect has the potential to influence organizational members in making changes. Vera and Crossan (2004) also provide a review of the different definitions of leadership and strategic leadership as conveyed by Hambrick and Pettigrew (2001).

Governance has a broad meaning and is often perceived as part of the disciplines such as political science, public administration, economics and management (Grossi et al., 2015a). Grossi et al. (2015b) also reinforced the review carried out in several definitions that apply in the context of corporate governance that is used by researchers in this field (Shleifer and Vishny, 1997; Colley et al., 2005; Tricker, 2012). Grossi et al. (2015b) explained that corporate governance refers to the exercise of power over corporate entities through the mechanism of directing, controlling and convincing stakeholders of financial sector to obtain a return on investment. In short, corporate governance refers to a system in which corporations are directed and controlled. Therefore, it is relevant to all forms of organizations state-owned enterprises (SOEs), family-based businesses, cooperatives, non-profit companies. In this case, corporate governance as part and emphasis of TO has relevance in this research due to the characteristics inherent in SOEs as a hybrid organization as reviewed by Grossi et al. (2015b). The main characteristics of SOEs today and the reason why they can succeed are their ability to adapt and take the form of new organizations (Musacchio and Lazzarini, 2014). A new form of hybrid organization by combining elements from different institutional logic (Pache and Santos, 2013). 
This research is one of the few research conducted on hospitality. Several previous researchers have studied hospitality at the airport (Albeshr and Ahmad, 2015), and several other researchers mostly conducted the research on hospital and hotel objects. This research was carried out at the port, where corporate hospitality is a discipline that covers a lot of marketing studies. For example, recorded in the time period between the 1990s and the early 2000s, this topic which has been linked to marketing studies has been widely discussed. Articles and academic research that emerged between these periods (Luckhurst, 1996; Chetwynd, 1998; Flack, 1999; Thatcher, 2000; Croft, 2001; Fletcher, 2001; Parker, 2001; Irwin, 2002; Bennett, 2003) are indications that the development of this concept has received relatively little attention since the initial article was introduced by Ramsay (1990) which was published in a "management decision" reputable journal. Looking at what has been presented in the literature, it can be seen that in the context of corporate hospitality, it is often identified with a corporate effort to entertain customers and employees to establish good relationships with them, for example by holding special events and giving prizes or bonuses.

Regarding some of the needs and analysis of the existing literature conditions, this research will focus on the context of strategic management of port business development in Indonesia for sustainable management. Sustainability has developed into an issue that has attracted the attention of various parties including researchers and academics (Aras and Crowther, 2008). Sustainability has also become an important central issue and its relevance is critical for the sustainability and economic viability of an organization (Salimath and Jones, 2011). Sustainability is a controversial topic because it will have different meanings for different people. However, there is increasing concern for the need to discuss the meaning of sustainability and crucially, the extent to which it can be done by the company (Aras and Crowther, 2008).

Sustainability achievement of a company, especially in Pelindo 1, one of which is pursued by transformation. The intended transformation includes Culture, Human Resources, and Organization, Business, Business Processes and IT Systems. Then in this research, transformation is placed as a concept. The concept in question is a characteristic of a broader and more abstract research object than variable. The definition of concepts also means that in a concept there are several variables. The purpose of this study is examining and explaining the effect of strategic leadership, corporate governance, organizational culture, business infrastructure and corporate alignment as determinants of corporate hospitality; testing and explaining the direct effects of corporate hospitality and corporate sustainability.

\section{Literature review and development of conceptual framework}

Strategic leadership (X1)

Patterson (2003) stated that the theory of Servant Leadership is the development of transformational leadership theory. In his findings, Parker and Stone (2003) stated that the choice to focus on others is the difference between Servant Leadership and Transformational Leadership. As a consequence, Servant Leadership is not a whole new concept or an idea that comes along with the arrival of Christianity. Before the birth of Jesus, many ancient writers, philosophers, historians, poetry creators and playwrights were concerned with the values, ideas and truths embedded in the concept of Greenleaf's Servant Leadership, such as Plato, Sophocles and Cicero. So, in this study Strategic Leadership is used as one of the independent variables that determine company friendliness.

\section{Organizational culture (X2)}

Kusdi (2011) stated that organizational culture is the values, beliefs, norms, rituals, symbols and stories shared together, which form the identity of the organization, its purpose and how
Determinant of $\mathrm{CH}$ and corporate sustainability 
ITPD

4,2

\section{8}

to achieve it. An organization besides requiring leadership, a sense of responsibility, commitment, cooperation and trust also requires a culture of mutual respect in running the organization. Mutual respect is the tolerance of fellow human beings, accepting differences between fellow human beings as a natural thing as long as it does not violate human rights (Ardiansyah, 2013). So, in this study Organizational Culture is used as one of the independent variables that determine company friendliness.

\section{Corporate governance (X3)}

World Bank's explanation of corporate governance cited by the Ministry of Home Affairs stated that corporate governance is a solid and accountable development management in line with the principles of democracy and efficient markets, avoidance of misallocation of investment funds, and prevention of good corruption politically and administratively, running budget discipline and creating legal and political frameworks for the growth of business activities. Corporate governance is the most important problem in the management of public administration today. Intense demands made by the community to the government to carry out good governmental accountability are in line with increasing the level of public knowledge in addition to the effect of globalization. The emergence of corporate governance does not only make the government an institution but also as a multi-direction process, involving elements of policy making outside the government such as the public and the private sector. By maximizing the role of the three elements, good governance will be realized based on the people (Purbawangsa et al., 2019). So, in this study corporate governance is used as one of the independent variables that determine company friendliness.

\section{Business infrastructure (X4)}

According to Grigg (2000) in Kodoatie (2005), basic structure, installation, equipment or facility that has been built to meet the needs of the community so that the economic and social system can run properly is an understanding of the infrastructure system. Here, infrastructure plays an important role as a mediator between the economic and social systems in the order of human life and the environment. This condition occurs so that the harmonization of life is maintained in the sense that infrastructure does not lack (impact on humans) but also not excessive without taking into account the carrying capacity of the natural environment because it will damage nature and ultimately, it will also affect humans and other living things. In this case, the natural environment is a supporter of infrastructure systems, and the economic system is supported by infrastructure systems, social systems as objects and targets supported by the economic system. So, in this study Business Infrastructure is used as one of the independent variables that determine company friendliness.

\section{Corporate alignment (X5)}

Corporate alignment according to Subagyo (2008) in a business feasibility study is a feasibility study conducted to assess the feasibility of developing a business. According to Umar (2005), a business feasibility study is a study of a business plan that does not only analyze the feasibility of a business, but also when it is routinely operated in order to achieve maximum profit for an unspecified time. If a leader or organization can align its future with a leadership plan in its management and with a personal plan, everything will be an extraordinary symbol of the organization of the future. Therefore, a leader must communicate the mission of his organization to all parts of the organization. Mission is a reference point, guide and source of hope in times of change. When connected with human values, it will provide goals and meanings to those who fulfill the mission and provide 
encouragement for creativity, productivity and quality in work and personal development. So, in this study Corporate Alignment is used as one of the independent variables that determine company friendliness.

\section{Corporate hospitality (Z)}

Corporate hospitality as a scientific discipline that encompasses many marketing studies. This also discusses what was conveyed by Drake (2013) which is more restrictive in the context of event management or the hospitality sector. This is because it is used to build trust and loyalty, establish or change customer identities and develop "word of mouth" as part of corporate communication (CC) to maintain profitable businesses and to acquire new customers (Bennett, 2003). Relationship marketing can last a long time if there is company friendliness, that is because friendliness can make trust and loyalty more increased, so it can shape the company's identity in the eyes of clients (Flack, 1999). So, in this study Corporate Hospitality is used as a mediating variable between the independent and dependent variables.

\section{Corporate sustainability (Y)}

Corporate sustainability can be interpreted as a diversion of business strategies and activities that meet the needs of companies and stakeholders while supporting, maintaining and improving human and natural resources that will be needed in the future (Searcy, 2011). The dimensions for measuring Corporate sustainability are Environmental, Social and Economic. So, in this study Corporate Sustainability is used as the dependent variables.

\section{Previous research}

Relationship relevance between strategic leadership (X1) on corporate hospitality (Z)

Dawson et al. (2011) in their research aimed to find ways for managers to communicate effectively with their employees. The results of this research indicated that effective nonverbal manager communication strategies, such as a combination of gestures, demonstrating and gesturing points, can help in manager communication with employees. Harrington and Ottenbacher (2011) in their research examined the level of representation of strategic management topics in hospitality academics. This research showed that researchers in general strategic management tended to focus on applications that were lacking and focused more on theoretical concepts about strategy, while researchers in hospitality strategic management tended to focus their attention on tactical methods when discussing strategic questions. Harrington et al. (2014) in his research reviewed the hospitality literature and tourism strategy to identify trends related to the main research fields. Okumus et al. (2007) in their research critically examined scientific studies in strategic management research in the fields of hospitality and tourism. Sanjeev and Jauhari (2012) in their research provided an overview of facts and trends related to the Indian hospitality industry, as well as identifying strategic keys and financial problems that businesses have. Sok et al. (2014) in their research discussed the impact of leadership styles on negative work-home disorders on highly educated employees in the hospitality industry.

\section{Relationship relevance between organizational culture (X2) on corporate hospitality (Z)}

Drake (2013) in his study discussed the practice of corporate hospitality $(\mathrm{CH})$ in special events used by Australian businesses as relationship marketing techniques to engage with their customers, investigated how marketing practitioners assess their $\mathrm{CH}$ programs in a business-tobusiness (B2B) context, determined the main benefits and uncovered contemporary problems faced by marketing practitioners in the operation of the CH program. IpKin and Jennifer (2014) in their research investigated the effect of corporate social responsibility (CSR) on employee affective
Determinant of $\mathrm{CH}$ and corporate sustainability 
ITPD

4,2

commitment through the mediation of corporate culture. The results of this research indicated that CSR to employees and CSR to customers were fully mediated by employee development, harmony and orientation of corporate culture customers, while CSR relations to stakeholders were only partially mediated. Jones et al. (2016) in their research discussed several personal reflections on sustainability in the hospitality industry. Jauncey and Nadkarni (2014) in their research highlighted and summarized the main findings of the theme issue: "Expo 2020: How are the hospitality and tourism industries in Dubai preparing themselves?" with interesting discussions and recommendations throughout the collection of articles to identify key success factors related to hosting the Expo 2020 in Dubai. Kang et al. (2016) in their research examining the effect of various national cultural dimensions on the activities of CSR of hospitality companies, including lodging companies, casinos and restaurants.

Relationship relevance between corporate governance (X3) on corporate hospitality (Z) Harrington $e t$ al. (2014) in their research aimed to review tourism and hospitality strategies, identify trends related to the two objects of research. Goede (2013) in his research discussed Transnational Organized Crime (TOC) and its relation to corporate governance in the Caribbean. Michael and Goo (2015) reviewed the latest developments in corporate governance in Hong Kong, to what extent government policies reduce family control in the companies. Ntongho (2016) in his research analyzed the relationship between culture and corporate governance. Okumus et al. (2007) in his research examined management strategies in the field of hospitality and tourism. Ruhanen et al. (2010) explored and synthesized the literature on corporate governance with the aim of identifying key elements of governance.

\section{Effects of business infrastructure (X4) on corporate hospitality (Z)}

Bora et al. (2015) conducted a research, in which the research was a literature review on the evaluation of service quality to determine the level of perceived quality of customer service, especially in evaluating customer quality. Rabbani et al. (2015) conducted a research which reviewed the need for formal hospital management training to improve the quality of care. Review was carried out at regional hospitals for Eastern Mediterranean Region (EMR) countries. Reino et al. (2011) in their research explained the direct relevance of the phenomenon of information and communication technology adopted by the rural accommodation sector. Rao (2014) examined the competitive world between the hospitality industry and the tourism industry.

\section{Effects of corporate alignment (X5) on corporate hospitality (Z)}

Adeola and Ezenwafor (2016) in their research aimed to advance collaboration as a solution to problems in the Nigerian hospitality industry. Anderson et al. (2017) in his research aimed to investigate the nature of public-private dialogue initiatives (PPD) and how PPD was used in the tourism and hospitality sector as a tool to reform the business environment (e.g. setting policy priorities, informing policy design, increasing legislative proposals and entering feedback into regulation implementation). Chen et al. (2017) in his research aimed to examine theoretical models of the dynamics of co-creation, service innovation and competitive advantage. Sloan et al. (2014) in his research aimed to report on the initial research conducted in seven sustainable hospitality and tourism operations that were established in developing countries that used the principles of social entrepreneurship.

Effect of corporate hospitality (Z) on corporate sustainability (Y)

Ali (2016) investigated the effect of the quality of Malaysian public university services on international student satisfaction, institutional image and loyalty. Crick and Spencer (2011) 
discussed issues related to the quality of services in the hospitality industry. Hosseini et al. (2015) conducted a study on the effect of hotel customer service performance on the quality of experience and brand loyalty in Iran. Tsang et al. (2015) compared Chinese and English literature about service quality in China. Rabbani et al. (2015) conducted research on the need for formal hospital management training to improve the quality of care.

\section{Methodology}

In accordance with its purpose, this study is intended for explanatory research that explains the causal relationship between variables studied through testing empirical hypotheses. The independent variables in this study are Strategic Leadership (X1), Organizational Culture $(X 2)$, Corporate Governance $(X 3)$, Business Infrastructure $(X 4)$, Corporate Alignment $(X 5)$. The dependent variable is Company Sustainability $(Y)$. Meanwhile, the Company's Hospitality variable becomes a mediating variable between the independent variable and the dependent variable (See Figures 1 and 2).

This research uses a quantitative approach with a survey method. Data collection was carried out by distributing questionnaires to selected respondents into the sample. Data collection was carried out for two months, namely between October and December 2018. This research was conducted at PT Pelindo 1 (Persero) Indonesia, so that the population in this study were the leaders of subsidiaries, branches and departments. The sample used in this study was 61 , where the sample consisted of 5 subsidiaries, 17 branches and 39 directorates from PT Pelindo 1 (Persero).

Data analysis was performed with inferential statistics using WarpPLS analysis using the help of a WarpPLS package computer program. Next, an analysis is conducted to examine the

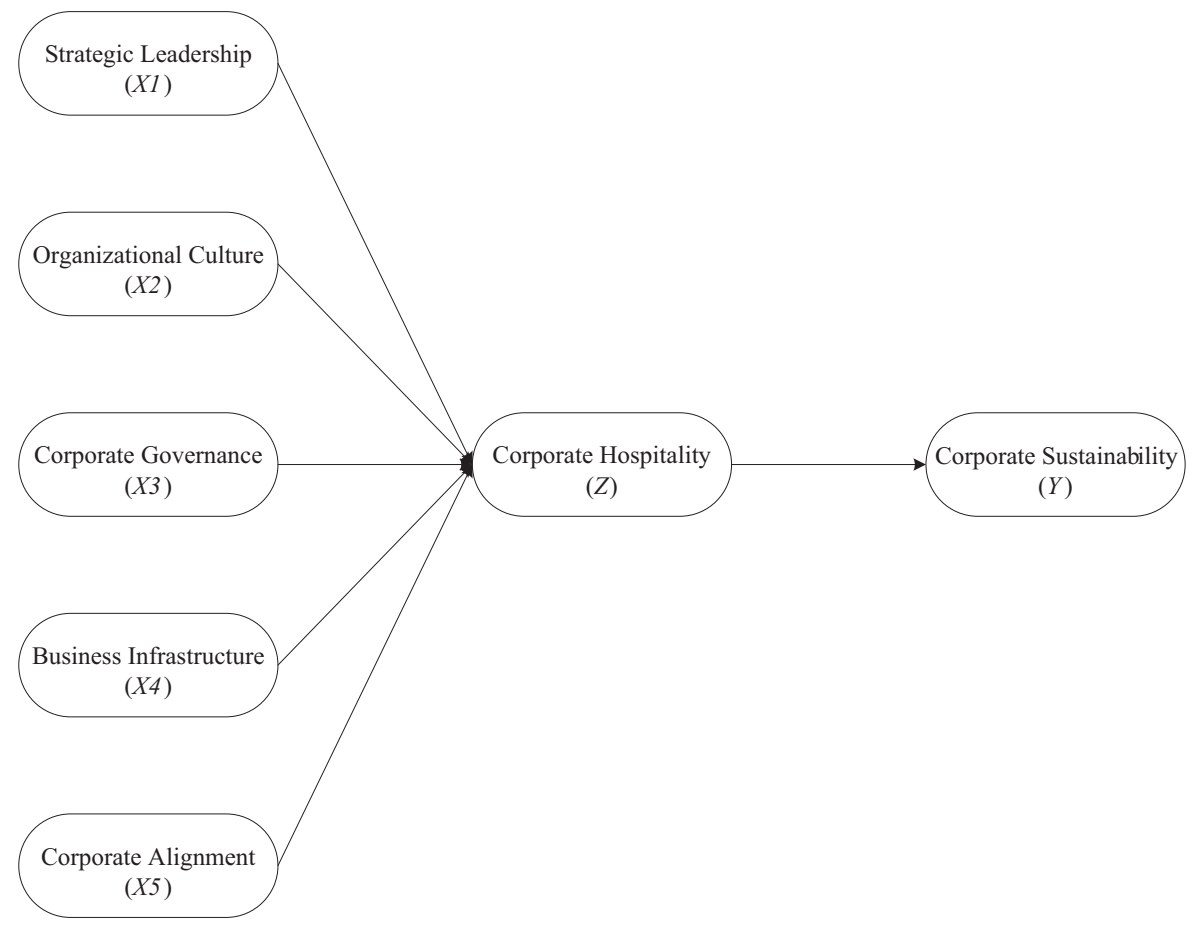

Determinant of $\mathrm{CH}$ and corporate sustainability

\section{1}


ITPD

4,2

relationship between the independent variable and the dependent variable with the linearity test analysis. Inferential analysis is used to test hypotheses with Structural Equation Modeling (SEM). Prior to the analysis, the research instrument will be tested for validity and reliability. The validity test of the research instrument was carried out if the total $r$ items corrected were at least 0.3 (Solimun et al., 2017). If the correlation of items with a total score is greater than critical $r$ (0.3), the research instrument is said to be valid. Then for reliability if it is done using Cronbach's alpha, if the value is above 0.6 then the questionnaire is reliable.

The research model is illustrated by the following chart:

\section{Description}

\section{X1: Strategic leadership}

An ability that is possessed in making others affected and in making decisions will make the organization successful and financially stable for a long time called strategic leadership. Strategic leadership consists of two indicators namely exploration innovation and explorative innovation.

\section{X2: Organizational culture}

The mode of interaction shown by people is influenced by the culture of the organization. Organizational culture consists of four indicators namely the type of organization, leadership, unifying organization and organizational priorities.

\section{X3: Corporate governance}

Corporate governance is the mechanisms, processes and relations by which corporations are controlled and directed. Corporate governance consists of four indicators namely transparency, accountability, predictability and participation.

\section{Business infrastructure (X4)}

Business infrastructure is the basic facilities, structures and services upon which the rest of a business is built. Business infrastructure consists of three indicators, namely aspects of resources, aspects of impacts and aspects of information communication technology (ICT).

\section{Corporate alignment (X5)}

Refers to the ongoing process every company goes through to keep the elements of the organization aligned with the organization's strategy and goals. Corporate alignment consists of five indicators namely strategic concept, work behavior, performance, appreciation and motivation.

\section{Corporate hospitality (Z)}

Is the entertainment that a company offers to its most valued clients, for example by inviting them to sporting events and providing them with food and drink. Corporate hospitality consists of four indicators namely profitability of corporate hospitality, corporate hospitality issues, strategic approach, satisfaction with corporate hospitality.

Corporate sustainability $(Y)$

Corporate sustainability is an approach aiming to create long-term stakeholder value through the implementation of a business strategy that focuses on the ethical, social, environmental, cultural and economic dimensions of doing business. Corporate sustainability consists of two indicators namely general triple bottom line, specific triple bottom line. 


\section{Results and discussion}

\section{Validity and reliability tests}

Before analyzing the relationship between variables, research instruments must first be tested for validity and reliability. The validity test on the instrument is done through Pearson correlation, that is by correlating the score of the indicator with the total score of all indicators. If the indicator is obtained a correlation value of more than 0.3 then the indicator is declared valid. Then, for reliability testing performed on each variable through Cronbach's alpha that is if the Cronbach's alpha value is obtained more than 0.6 then the variable can be said to be reliable. The results of validity and reliability testing are presented in Table 1.

From the results of testing the validity, obtained correlation values of more than 0.3 for all indicator variables. So, this proves that the questionnaire is valid. Then, for the reliability test results, Cronbach's alpha values obtained above 0.6 for all variables. So, this proves that this research instrument is reliable. Then, further analysis can be done.

\section{Linearity assumption test}

The third assumption test, namely linearity, was done using the Curve Fit method and calculated with the help of SPSS software. The reference used was the principle of parsimony, i.e. when (1) the linear model is significant, (2) the linear model is not significant, but all models
Determinant of $\mathrm{CH}$ and corporate sustainability

\begin{tabular}{|c|c|c|c|c|c|c|}
\hline Variable & Indicator & $\begin{array}{l}\text { Pearson } \\
\text { correlation }\end{array}$ & $\begin{array}{c}\text { Cronbach's } \\
\text { alpha }\end{array}$ & $\begin{array}{l}\text { Validity } \\
\text { status }\end{array}$ & $\begin{array}{l}\text { Reliability } \\
\text { status }\end{array}$ & \\
\hline Strategic & Exploratory Innovation & 0.533 & \multirow[t]{2}{*}{0.733} & Valid & \multirow[t]{2}{*}{ Reliable } & \\
\hline Leadership (X1) & Exploitative Innovation & 0.464 & & Valid & & \\
\hline Organizational & Organization Type & 0.316 & \multirow[t]{4}{*}{0.693} & Valid & \multirow[t]{4}{*}{ Reliable } & \\
\hline \multirow[t]{3}{*}{ Culture $(X 2)$} & Leadership & 0.454 & & Valid & & \\
\hline & Organization Unifier & 0.599 & & Valid & & \\
\hline & Organization Priority & 0.402 & & Valid & & \\
\hline Corporate & Transparency & 0.511 & \multirow[t]{4}{*}{0.755} & Valid & \multirow[t]{4}{*}{ Reliable } & \\
\hline \multirow{3}{*}{ Governance $(X 3)$} & Accountability & 0.523 & & Valid & & \\
\hline & Predictability & 0.389 & & Valid & & \\
\hline & Participation & 0.374 & & Valid & & \\
\hline Business & Resource Aspect & 0.444 & \multirow[t]{5}{*}{0.777} & Valid & \multirow[t]{5}{*}{ Reliable } & \\
\hline \multirow[t]{4}{*}{ Infrastructure $(X 4)$} & Impact Aspect & 0.379 & & Valid & & \\
\hline & Information & 0.421 & & Valid & & \\
\hline & Communication & & & & & \\
\hline & Technology (ICT) Aspect & & & & & \\
\hline Corporate & Strategic Concept & 0.464 & \multirow[t]{5}{*}{0.783} & Valid & \multirow[t]{5}{*}{ Reliable } & \\
\hline \multirow{4}{*}{ Alignment $(X 5)$} & Work Behavior & 0.466 & & Valid & & \\
\hline & Performance & 0.511 & & Valid & & \\
\hline & Reward & 0.403 & & Valid & & \\
\hline & Motivation & 0.447 & & Valid & & \\
\hline \multirow{7}{*}{$\begin{array}{l}\text { Corporate } \\
\text { Hospitality }(Z)\end{array}$} & Advantages of Corporate & 0.647 & \multirow[t]{7}{*}{0.682} & Valid & \multirow[t]{7}{*}{ Reliable } & \\
\hline & Hospitality & & & & & \\
\hline & Problems of Corporate & 0.435 & & Valid & & \\
\hline & Hospitality & & & & & \\
\hline & Strategic Approach & 0.333 & & Valid & & \\
\hline & Satisfaction on Corporate & 0.374 & & Valid & & \\
\hline & Hospitality & & & & & \\
\hline \multirow{3}{*}{$\begin{array}{l}\text { Corporate } \\
\text { Sustainability }(Y)\end{array}$} & General Triple Bottom & 0.563 & \multirow[t]{3}{*}{0.820} & Valid & \multirow[t]{3}{*}{ Reliable } & \\
\hline & Line & & & & & Table 1. \\
\hline & $\begin{array}{l}\text { Specific Triple Bottom } \\
\text { Line }\end{array}$ & 0.538 & & Valid & & $\begin{array}{r}\text { Validity and } \\
\text { reliability test }\end{array}$ \\
\hline
\end{tabular}


ITPD

4,2

\section{4}

that are possible are also not significant. Model specifications used as the basis for testing were linear, quadratic, cubic, inverse, logarithmic, power, compound, growth and exponential models. The results of linearity test on the relationship between variables are presented briefly in Table 2 .

The table above shows the three relationships between variables (three hypotheses), all linear models are significant, because the sig ( $p$-value) of linear model is smaller than 0.05 , therefore the linearity assumption is fulfilled. Thus, the five relationships between variables in this research are linear. Thus, SEM can be used.

\section{Goodness-of-fit model}

Based on $R^{2}$ value, $Q^{2}$ or Stone Geiser $Q$-square test can be calculated, namely:

$$
\begin{aligned}
& Q^{2}=1-\left(1-R_{1}^{2}\right)\left(1-R_{2}^{2}\right) \\
& Q^{2}=1-(1-0.622)(1-0.421) \\
& Q^{2}=0.7811=78.11 \%
\end{aligned}
$$

Based on the calculation results, it is obtained the relevance-prediction value of 0.7811 . This shows that, for $78.11 \%$ of the diversity of data can be explained by the variables in the model, then the other $21.89 \%$ can be explained by other variables outside the model. The relevanceprediction value obtained is large enough so that the model formed can be said to be correct.

\section{Inner model test results}

Structural models can be used to determine the relationship between one variable with another in the study. If the $p$-value is less than 0.05 , it indicates that there is an influence between these variables. In SEM analysis, there are direct and indirect effects. Table 3 presents the results of the analysis for direct effects between variables. Then, the direct effect has been presented in Table 3 .

The conclusions of the results of hypothesis test of the direct effect are summarized in Table 3 to facilitate understanding. In accordance with the empirical results, it can be

Table 2.

Linearity assumption test

\begin{tabular}{lcc}
\hline Relationship & Test & Result \\
\hline$X 1 \rightarrow Z$ & $0.000<0.05$ & Linear \\
$X 2 \rightarrow Z$ & $0.000<0.05$ & Linear \\
$X 3 \rightarrow Z$ & $0.000<0.05$ & Linear \\
$X 4 \rightarrow Z$ & $0.000<0.05$ & Linear \\
$X 5 \rightarrow Z$ & $0.000<0.05$ & Linear \\
$Z \rightarrow Y$ & $0.000<0.05$ & Linear \\
\hline
\end{tabular}

Table 3.

Direct effect test results 6

\begin{tabular}{llccc}
\hline No & Relationship & Coefficient & p-value & Remarks \\
\hline 1 & Strategic Leadership (X1) on Corporate Hospitality (Z) & 0.277 & 0.001 & Significant \\
2 & Organizational Culture (X2) on Corporate Hospitality (Z) & 0.209 & 0.009 & Significant \\
3 & Corporate Governance (X3) on Corporate Hospitality (Z) & 0.281 & 0.000 & Significant \\
4 & Business Infrastructure (X4) on Corporate Hospitality (Z) & 0.311 & 0.000 & Significant \\
5 & Corporate Alignment (X5) on Corporate Hospitality (Z) & 0.288 & 0.010 & Significant \\
6 & Corporate Hospitality (Z) on Corporate Sustainability (Y) & 0.389 & 0.008 & Significant \\
\hline
\end{tabular}




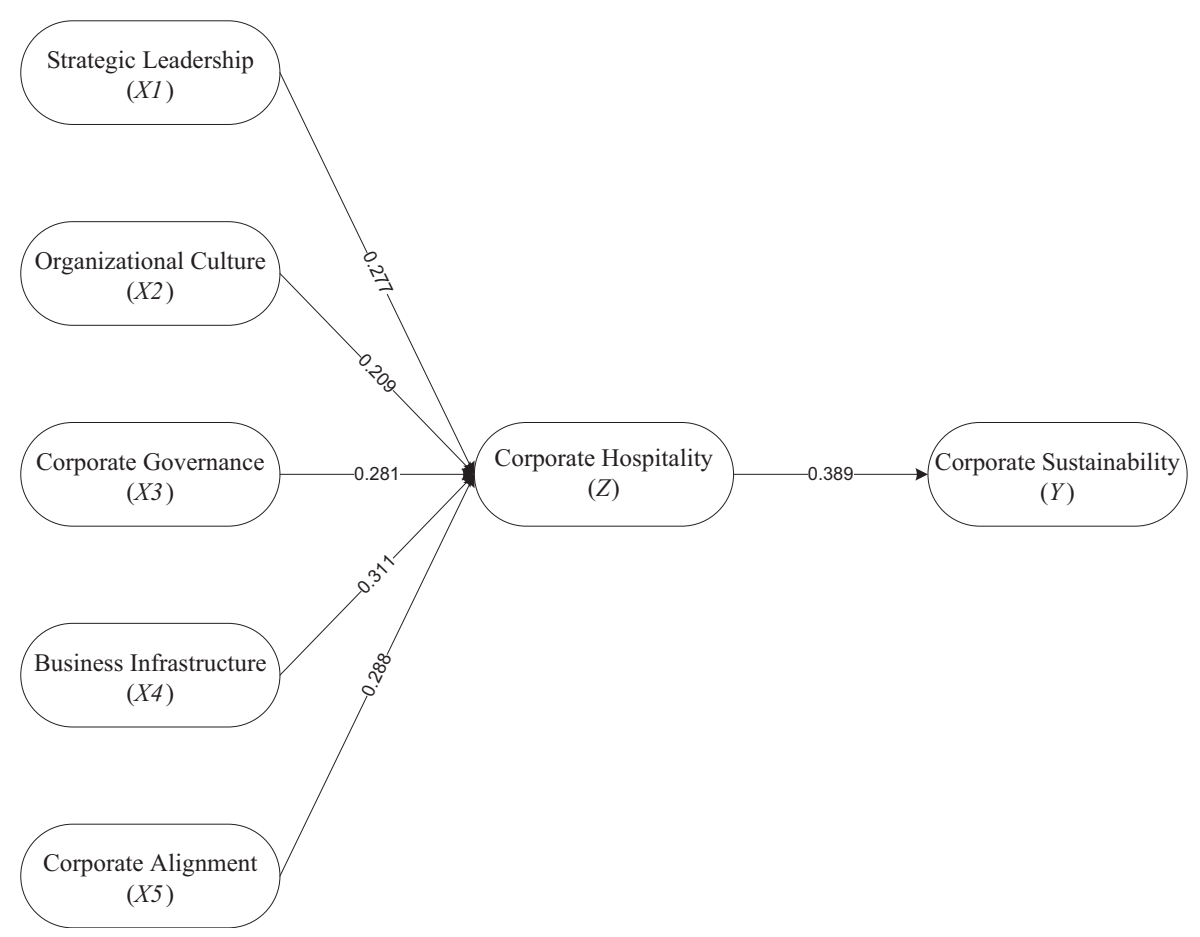

Determinant of $\mathrm{CH}$ and corporate sustainability

115

concluded that there are three significant and proven hypotheses which are empirically supported by data. Thus it can be said that all three hypotheses are accepted and all have positive effects.

Based on Table 4, it can be seen that there are five significant and positive indirect effects on the relationship of Strategic Leadership, Organizational Culture, Corporate Governance, Business Infrastructure and Corporate Alignment on Corporate Sustainability through Corporate Hospitality.

\section{Discussion}

Relationship between strategic leadership and corporate hospitality

The results of the analysis show that there is a positive and significant effect between Strategic Leadership and Corporate Hospitality with a coefficient of 0.277 , and $p$-value of 0.001. This means that the higher Strategic Leadership will result in higher Corporate Hospitality. In addition, there is an indirect effect between Strategic Leadership on Corporate

\begin{tabular}{|c|c|c|c|c|c|}
\hline \multirow{2}{*}{$\frac{\text { Indirect effect }}{X 1 \rightarrow Z \rightarrow Y}$} & \multicolumn{2}{|c|}{ Direct effect coefficient } & \multirow{2}{*}{$\frac{\text { Indirect effect coefficient }}{0.108}$} & \multirow{2}{*}{$\frac{\text { Remarks }}{\text { Sig }}$} & \\
\hline & $X 1 \rightarrow Z=0.277^{*}$ & $Z \rightarrow Y=0.389^{*}$ & & & \\
\hline$X 2 \rightarrow Z \rightarrow Y$ & $X 2 \rightarrow Z=0.209^{*}$ & $Z \rightarrow Y=0.389^{*}$ & 0.081 & Sig & \\
\hline$X 3 \rightarrow Z \rightarrow Y$ & $X 3 \rightarrow Z=0.281 *$ & $Z \rightarrow Y=0.389 *$ & 0.109 & $\mathrm{Sig}$ & Table 4 \\
\hline$X 4 \rightarrow Z \rightarrow Y$ & $X 4 \rightarrow Z=0.311^{*}$ & $Z \rightarrow Y=0.389 *$ & 0.121 & Sig & Indirect effect test \\
\hline$X 5 \rightarrow Z \rightarrow Y$ & $X 5 \rightarrow Z=0.288^{*}$ & $Z \rightarrow Y=0.389 *$ & 0.112 & Sig & results \\
\hline
\end{tabular}


ITPD

4,2

116

Sustainability through Corporate Hospitality. Coefficients with positive signs mean that the higher Strategic Leadership will influence the higher Corporate Sustainability through Corporate Hospitality.

This research is in line with the research conducted by Dawson et al. (2011) which aimed to find ways for managers to communicate effectively with their employees. This research was conducted on 167 students majoring in hospitality and restaurant management with an average age of 22 years. As many as $68 \%$ of participants in this research worked side-by-side in the hospitality industry with $38 \%$ of Caucasians, $29 \%$ of Asians, $18 \%$ of Hispanics, $10 \%$ of African-Americans and $5 \%$ of other races. This research used perspective-taking manipulation techniques with participants likened to not being able to speak using the colloquial language of the workplace. This group was measured based on performance, quality and accuracy. The results of this research indicated that effective non-verbal manager communication strategies, such as a combination of gestures, demonstrating and gesturing points, could help in manager communication with employees. Managers who used this strategy caused employees to complete their work faster. Managers who were able to speak other languages could also behave more positively towards their group. This group also stated that they could behave more positively towards each other when they had a leader or manager who used two languages.

Harrington and Ottenbacher (2011) in their study examined the level of representation of strategic management topics in hospitality academics. This research was conducted by looking at the number and percentage of strategy-related articles published in well-known hotel journals throughout 2005 to 2009 . This research compared hotel journals with single top business journals that focused on strategy. This research showed that researchers in general strategic management tended to focus on applications that were lacking and focused more on theoretical concepts about strategy, while researchers in hospitality strategic management tended to focus their attention on tactical methods when discussing strategic questions.

Harrington et al. (2014) in their research reviewed the hospitality literature and tourism strategy to identify trends related to the main research fields. Previous research in the hospitality strategy literature has been reviewed and synthesized to identify trends, gaps and opportunities. From literature assessments from 1980 to 2013, it can be concluded that literature follows mainstream trends by combining a theoretical perspective to a certain degree and applying more process-based concepts to hospitality strategy research. There are a number of challenges to fostering a future capitalistic strategy including education infrastructure, theory development and quantity and quality of researchers in the field.

Okumus et al. (2007) in his research critically examined scientific studies in strategic management research in the fields of hospitality and tourism. This research was conducted through literature review based on three dimensions, namely the intellectual, conceptual and social structure of strategic management research. This research found that based on these three dimensions, strategic management in the field of hospitality and tourism showed a discursive structure.

Sanjeev and Jauhari (2012) in their research provided an overview of facts and trends related to the Indian hospitality industry, as well as identified strategic keys and financial problems that businesses have. This research was carried out by drawing on facts and trends that emerged from various official reports and compiling key issues as highlighted by contributors to related theme issues. This research found that some of the main areas that emerged from the extended period of inflation were risk management, cost management, land management and policy, revenue management, growth challenges and innovative practices.

Tromp and Blomme (2014) in their research found that an autocratic leadership style, overtime work and lack of work-home settings contributed significantly to the negative disruption of work-home employee. 
Top of Form Bottom of Form Top of Form

\section{Bottom of Form}

Relationship between organizational culture and corporate hospitality. The results of the analysis show that there is a significant effect between Corporate Culture on Corporate Hospitality, which is shown by the coefficient value of 0.209 and $p$-value of 0.009 . This means that the higher the Corporate Culture will result in higher Corporate Hospitality. In addition, there is an indirect effect between Corporate Culture on Corporate Sustainability through Corporate Hospitality. Positive coefficient means that the higher the Corporate Culture will affect the higher Corporate Sustainability through Corporate Hospitality.

This research is in line with the research conducted by Drake (2013) in his study, which discussed the practice of corporate hospitality $(\mathrm{CH})$ in special events used by Australian businesses as relationship marketing techniques to engage with their customers, investigated how marketing practitioners assessed their $\mathrm{CH}$ programs in a business-tobusiness (B2B) context and determined the main benefits and uncovered contemporary problems faced by marketing practitioners in the operation of the $\mathrm{CH}$ program.

Jones et al. (2016) in their research discussed several personal reflections on sustainability in the hospitality industry. In general, the researchers suggested three fundamental issues regarding the issues currently facing the industry, namely, determining sustainability in the industry, materiality and independent external guarantees and sustainable consumption and industry commitment to sustainable economic growth.

Kang et al. (2016) in their research found a positive and significant effect of uncertainty avoidance on the total CSR value. Furthermore, the results of the study indicated a positive and significant effect of the distance of power both on positive and negative CSR values, while the distance of power in total CSR had no significant effect. Individualism had a negative and significant effect on both positive and negative CSR values. Masculinity had a negative and significant effect on positive CSR values.

Malhotra and Venkatesh (2009) in their research evaluated and suggested guidelines for developing crisis management plans in the pre-crisis period. This could have a significant effect on the growth of the company, industry and economy. Based on a crisis management literature review, key issues have been identified, a lack of planning before the crisis has been witnessed and then the existing models have been adjusted to be used in a generic format to prepare contingency plans. The results of this research resulted in an analysis of various problems related to the readiness to overcome different crises, types and stages of crisis, the relative impact of these negative events on the hotel and tourism industry, the gaps found in crisis management strategies and lessons learned.

Murray et al. (2017) explored the challenges faced by the hospitality and tourism industry in managing the employment challenges faced today and will be faced in the coming years. This paper referred to insights from three industry members and two academics to explore key areas where action can be taken to address the challenges of labor demand in the field of hospitality and tourism employment. Canadian hospitality and tourism industry faced a growing demand for labor. Industry members can deal with this in various fields, from satisfaction of frontline employees to other regional and national advocacy efforts. This research recommended the industry to do a combination of activities.

Top of Form Bottom of relationship between corporate governance and corporate hospitality. The results of the analysis show that there is a positive significant effect between Corporate Governance on Corporate Hospitality with a coefficient of 0.281 and $p$-value of 0.000 . This means that the higher the Corporate Governance will result in the higher Corporate Hospitality. In addition, there is an indirect effect between Corporate Governance on Corporate Sustainability through Corporate Hospitality. The coefficient with positive sign means that the higher the Corporate Governance will affect the higher Corporate Sustainability through Corporate Hospitality.

\section{Determinant of $\mathrm{CH}$ and corporate sustainability}


ITPD

4,2

118

This research is in line with research conducted by Harrington et al. (2014) which aimed to review tourism and hospitality strategies, identify trends related to the two objects of research. Hotel strategy research continuously enhances and broadens the limits of thought that exist in the hospitality literature. Previous literature, from 1980 to 2013, it seems clear that it still follows mainstream trends where it combines theoretical perspectives and also applies process-based concepts. There are several challenges to pushing the hotel strategy forward, including education infrastructure, theory development and quantity and the quality of researchers in the field.

Goede (2013) in this research discussed Transnational Organized Crime (TOC) and its relation to corporate governance in the Caribbean. Based on this research, it can be seen that the effect of the TOC on governance in the Caribbean was very worrying.

Michael and Goo (2015) reviewed the latest developments in corporate governance in Hong Kong, to what extent government policies reduced family control in the companies. The researcher used a comparative corporate governance approach which showed various corporate governance theories of companies in Hong Kong. The researcher found that in Hong Kong companies, excessive executive compensation, weak accounting and auditing did not cause the same problems as in other countries.

Ntongho (2016) in his research analyzed the relationship between culture and corporate governance. In particular, this research has increased the impact of culture in inhibiting corporate governance convergence. Overall, this paper provided an assessment of corporate governance laws in oriented countries. To determine the effect of culture in corporate governance convergence, the researchers used historical trends in analyzing changes in corporate governance policies in six countries (covering three continents) and in forming corporate governance models oriented to stakeholders. This research showed nominal changes in regulations and corporate governance ideologies, this was because the countries still turn to designing corporate governance rules around their cultural philosophy. This research also revealed weak political researcher for the convergence of market forces.

Okumus et al. (2007) examined management strategies in the field of hospitality and tourism. This research was conducted through a literature review approach based on three dimensions: intellectual, conceptual and social structure of management strategy research. Based on these three components, management strategies in the field of hospitality and tourism showed a discursive structure.

Ruhanen et al. (2010) explored and synthesized the literature on corporate governance with the aim of identifying key elements of governance. The main objective of this research was to identify the main elements and factors that have been applied in corporate governance studies so far. A review of 53 research on corporate governance identified 40 dimensions of governance separately. From this review, it was known that the six dimensions of corporate governance that were most often included were: accountability, transparency, involvement, structure, effectiveness and power.

Top of Form Bottom of Form Relationship between business infrastructure and corporate hospitality. The analysis shows that there is a positive significant effect between Business Infrastructure on Corporate Hospitality with a coefficient of 0.311 and a $p$-value of 0.000 . This means that the higher the Business Infrastructure will result in the higher Corporate Hospitality. In addition, there is an indirect effect between Business Infrastructure on Corporate Sustainability through Corporate Hospitality. The coefficient with positive sign means that the higher the Business Infrastructure will affect the higher Corporate Sustainability through Corporate Hospitality.

This research is in line with the research of Bora et al. (2015) which is a literature review on the evaluation of service quality to determine the level of perceived quality of customer service, especially in evaluating customer quality. Analysis in this research used multivariate 
variance to examine significant differences between stakeholder perceptions of service quality, using a sample of 845 hotels (customers, employees and managers). The findings showed that based on employee perceptions, service performance was at a high level, while customers felt service performance was still at a low level.

Rabbani et al. (2015) reviewed the need for formal hospital management training to improve the quality of care. Review was carried out at regional hospitals for Eastern Mediterranean Region (EMR) countries. The majority of patients in the EMR went through or ignored primary health care facilities because of inadequate quality of service and preferred to seek special care at the tertiary level. Training such as disaster management, utilization of health management information systems, support services, biomedical engineering, transportation and waste management would help prepare health care professionals with leadership skills to provide quality hospital services.

Reino et al. (2011) explained the direct relevance of the phenomenon of information and communication technology adopted by the rural accommodation sector. The purpose of this research was to examine differences in the level of technology adoption between companies between rural and urban companies in a major tourist destination in Scotland. The method used in this research was the survey method and the results showed that the difference in the level of technology adoption was divided into two, namely a system that required infrastructure and applications in particular sectors. This research showed that between growth theory and neoclassical theory both contradicted each other, but complementarily both explained the different levels of adoption between rural and urban enterprise arrangements.

Rao (2014) examined the competitive world between the hospitality industry and the tourism industry. It was important that achieving a professional career required skills in developing a business foundation and good customer service. There were several main themes to promote the hospitality and tourism industry, namely international tourism planning, hotel development and operation, planning and engineering issues, service improvement, finance and performance and management psychology. The objective of this research was to identify, analyze and record the future trends that have been carried out now related to hospitality and the tourism sector. This kind of study will really help to identify progress and some gaps in this field, thus helping to build tourism research that is more efficient, effective and accountable to support practical work.

Sharma (2016) as assumed by the health ecology model, improving nutrition and physical activity in the workplace can facilitate healthy food intake and physical activity patterns of employees, so that in this research a cross-sectional study was carried out to describe current policies and practices targeted. In assessing policy, this research used survey methods as an environmental assessment tool and observation tool. The results of this research indicated there were deficiencies in policies and practices, including a lack of policies that supported physical employees, no healthy catering or healthy meeting policies, at least subsidize healthy food and beverage choices and a few food sales services that promote health. In active hospitals, staff health was consistently better in implementing policies and practices in supporting healthy food and physical activity.

Yeoman et al. (2013) described New Zealand tourism in the future based on the philosophy of sustainability and cultural identity in response to the current Tourism Strategy of 2025. New Zealand Wonderland Scenario described a future based on an international reputation based on environmentalism that was driven by good governance, climate change targets and ecotourism.

Top of Form Bottom of form relationship between corporate alignment and corporate hospitality. The results of the analysis show that there is a significant positive effect between Corporate Alignment on Corporate Hospitality with a coefficient of 0.288 and a $p$-value of 0.010 . This means that the higher the Corporate Alignment will result in higher Corporate Hospitality. In addition, there is an indirect effect between Corporate Alignment on Corporate
Determinant of $\mathrm{CH}$ and corporate sustainability 
ITPD

4,2

120

Sustainability through Corporate Hospitality. The coefficient with positive sign means that the higher the Corporate Alignment will affect the higher Corporate Sustainability through Corporate Hospitality.

This research is in line with the research conducted by Adeola and Ezenwafor (2016) which aimed at advancing collaboration as a solution to problems in the Nigerian hospitality industry. The results of this research indicated that the operating environment of the hospitality sector in Nigeria had an effect on the supply of skills and financial performance of restaurants and similar hospitality businesses, while to improve overall industry performance, private-public partnerships between government agencies, hospitality colleges and hospitality businesses, strategic partnerships between expert hospitality institutions and business schools, collaboration between hotel business owners and improved managerial practices can be a strategic step for industrial operations under the heavy institutional constraints typical of Nigeria.

Based on study conducted by Sloan et al. (2014) conclude that the positive effects of hiring indigenous people on these projects were far greater than some negative aspects. Job opportunities that led to an increase in living standards have resulted in each case. Local cultural traditions have been maintained and only in a few cases were examples of the negative effects of tourism reported.

Strobl and Kronenberg (2016) in their research aimed to provide a detailed understanding of the dynamics of entrepreneurial networks throughout the life cycle of a hospitality company. The results of this research indicated the hospitality business network was shifting from local relations to industry groups specifically to local and non-local ties to groups of actors within and outside the industry. Throughout the life cycle of company, entrepreneurs preferred strong bonds. The transition from one generation of family to the next and changes in a competitive environment were important triggers of network configuration.

Relationship between corporate hospitality and corporate sustainability. The results of the analysis show that there is a positive significant effect between Corporate Hospitality on Corporate Sustainability with a coefficient of 0.389 and $p$-value of 0.008 . This means that the higher the Corporate Hospitality will result in higher Corporate Sustainability.

This research is in line with the research of Ali (2016) which investigated the effect of the quality of Malaysian public university services on international student satisfaction, institutional image and loyalty. The results of the study showed that the quality of education services influenced students' satisfaction which can also affect the institutional image and student loyalty.

Crick and Spencer (2011) discussed issues related to the quality of services in the hospitality industry. Companies found out about customer satisfaction with their services, reflecting the intention of a company to meet consumer needs. This detailed monitoring approach referred to as the "QFD flow process" allowed companies to adjust consumer needs to every aspect of operations and increase the likelihood that what was provided was the satisfaction expected by consumers. Companies needed to measure consumer expectations at each stage to create services that exceeded consumers' expectations to compete with other companies.

Hosseini et al. (2015) conducted a research on the effect of hotel customer service performance on the quality of experience and brand loyalty in Iran. Direct experience of service performance in the hotel industry consisted of three main components, namely interaction with hotel and customer employees, service environment, and service outcomes. In this research, it was found that direct and indirect experience of service performance contributed to the formation of brand image and brand loyalty.

Based on research from Rabbani et al. (2015) concluded that hospital management capacity must be improved by conducting formal training programs in order to improve the performance of health service delivery and the overall health system. From the training will be able to improve health care professionals, so that the services provided are of high quality. 
In increasing customer satisfaction and loyalty to their store, most owners will run a loyalty program. Research conducted by Zakaria et al. (2014) have found that loyalty programs and customer satisfaction are proven to have a relationship. Thus, this shows that the presence of loyalty programs such as prizes has proven effects on customer loyalty and satisfaction.

\section{Conclusion}

The conclusions obtained from the results of the analysis that has been done namely,there is a significant and positive direct effect between Strategic Leadership, Corporate Culture, Corporate Governance, Business Infrastructure, and Corporate Alignment on Corporate Hospitality which means higher Strategic Leadership, Corporate Culture, Corporate Governance, Business Infrastructure, and Corporate Alignment will result in a higher Corporate Hospitality. The analysis also shows that there is a significant and positive indirect effect between Strategic Leadership, Corporate Culture, Corporate Governance, Business Infrastructure and Corporate Alignment on Corporate Sustainability through Corporate Hospitality which means higher Strategic Leadership, Corporate Culture, Corporate Governance, Business Infrastructure and Corporate Alignment will lead to higher Corporate Sustainability through Corporate Hospitality.

This research has limitation, namely it only examined the variables of Strategic Leadership, Corporate Culture, Corporate Governance, Business Infrastructure, Corporate Alignment and Corporate Hospitality. It is hoped that the concept of corporate hospitality can be developed in a more strategic context where corporate hospitality in a narrow sense is often associated with discussions in tourism literature, event management and service industry. In addition, it is hoped that further research can develop the concept and context of corporate hospitality that has more holistic relevance than the current definition.

Besides companies, hospitality behavior is also needed by PT Pelindo 1 (Persero) to determine company sustainability, through Strategic Leadership, Corporate Culture, Corporate Governance, Business Infrastructure and Corporate Alignment. Thus, the port business in Indonesia for sustainable management can be further developed. It is expected that the results of this research can be a source of information for designing company strategies and policies in order to encourage business growth and realize company sustainability at PT Pelindo 1 (Persero).

\section{Recommendation}

The recommendations for PT Pelindo are as follows: Improving the sustainability of the company can be pursued through the priority of enhancing strategic leadership, through the development of explorative and exploitative innovations. Hospitality and corporate reputation are variables that play an important role in enhancing the sustainability of the company with the priority of increasing strategic leadership.

\section{References}

Adeola, O. and Ezenwafor, K. (2016), "The hospitality business in Nigeria: issues, challenges and opportunities", Worldwide Hospitality and Tourism Themes, Vol. 8 No. 2, pp. 182-194.

Albeshr, H. and Ahmad, S.Z. (2015), "Service innovation by Dubai international airport: the battle to remain competitive", Emerald Emerging Markets Case Studies, Vol. 5, pp. 1-18.

Ali, F. (2016), "Does higher education service quality effect student satisfaction, image and loyalty?: a study of international students in Malaysian public universities", Quality Assurance in Education, Vol. 24 No. 1, pp. 70-94. 
ITPD

4,2

Anderson, W., Busagara, T., Mahangila, D., Minde, M., Olomi, D. and Bahati, V. (2017), "The dialogue and advocacy initiatives for reforming the business environment of the tourism and hospitality sector in Tanzania”, Tourism Review, Vol. 72 No. 1, pp. 45-67.

Aras, G. and Crowther, D. (2008), "Governance and sustainability: an investigation into the relationship between corporate governance and corporate sustainability", Management Decision, Vol. 46 No. 3, pp. 433-448.

Ardiansyah, J.T. (2013), The Effect of Price, Brand Image and Brand Personality on Brand Preferences on the Hewllet Packard (HP) Laptop, Doctoral Dissertation, Stie Perbanas Surabaya.

Barney, J. (1991), "Firm resources and sustained competitive advantage", Journal of management, Vol. 17 No. 1, pp. 99-120.

Bennett, W.L. (2003), "The burglar alarm that just keeps ringing: a response to Zaller", Political Communication, Vol. 20 No. 2, pp. 131-138.

Bora, D.B. (2015), "Differences in service quality perceptions of stakeholders in the hotel industry", International Journal of Contemporary Hospitality Management, Vol. 27 No. 1, pp. 130-146.

Chen, J., Kerr, D., Chou, C.Y. and Ang, C. (2017), "Business co-creation for service innovation in the hospitality and tourism industry", International Journal of Contemporary Hospitality Management, Vol. 29 No. 6, pp. 1522-1540.

Chetwynd, C. (1998), “Corrupt hospitality”, Marketing Week, Vol. 5, pp. 47-50.

Colley, J.L., Doyle, J., Dogan, G.L. and Stettinius, W. (2005), What is Corporate Governance?, McGraw Hill, New York, NY.

Croft, W. (2001), Radical Construction Grammar: Syntactic Theory in Typological Perspective, Oxford University Press on Demand.

Crick, P.A. and Spencer, A. (2011), "Hospitality quality: new directions and new challenges", International Journal of Contemporary Hospitality Management, Vol. 23 No. 4, pp. 463-478.

Dawson, M.A., Prinjha, R.K., Dittmann, A., Giotopoulos, G., Bantscheff, M., Chan, W.I., Robson, S.C., Chung, C.W., Hopf, C., Savitski, M.M., Huthmacher, C., Gudgin, E., Lugo, D., Beinke, S., Chapman, T.D., Roberts, E.J., Soden, P.E., Auger, K.R., Mirguet, O., Doehner, K., Delwel, R., Burnett, A.K., Jeffrey, P., Drewes, G., Lee, K., Huntly, B.J. and Kouzarides, T. (2011), "Inhibition of BET recruitment to chromatin as an effective treatment for MLL-fusion leukaemia", Nature, Vol. 478 No. 7370 , p. 529.

Drake, C.N. (2013), "Maximising effectiveness of corporate hospitality programmes at Australian special events", International Journal of Event and Festival Management, Vol. 4 No. 3, pp. 236-248.

Flack, J. (1999), "Slump action", Marketing Week, 4 March, pp. 57-9.

Fletcher, J.K. (2001), Disappearing Acts: Gender, Power, and Relational Practice at Work, MIT Press, Massachusetts.

Goede, M. (2013), "Transnational organized crime (TOC) and the relationship to corporate governance in the Caribbean: transnational organized crime democracy (TOCD)", International Journal of Development Issues, Vol. 12 No. 3, pp. 253-270.

Grigg, N.S. (2000), "Where are we in infrastructure education?”, Public Works Management and Policy, Vol. 4 No. 3, pp. 256-259.

Grossi, G., Papenfuß, U. and Tremblay, M.S. (2015a), "Corporate governance and accountability of state-owned enterprises: relevance for science and society and interdisciplinary research perspectives", International Journal of Public Sector Management, Vol. 28 Nos 4-5, pp. 274-285.

Grossi, G., Perski, A., Osika, W. and Savic, I. (2015b), "Stress-related exhaustion disorder-clinical manifestation of burnout? A review of assessment methods, sleep impairments, cognitive disturbances, and neuro-biological and physiological changes in clinical burnout, Scandinavian”, Journal of Psychology, Vol. 56 No. 6, pp. 626-636. 
Hambrick, D. and Pettigrew, A. (2001), "Upper echelons: Donald Hambrick on executives and strategy", Academy of Management Executive, Vol. 15 No. 3, pp. 36-44.

Harrington, R.J. and Ottenbacher, M.C. (2011), "Strategic management: an analysis of its representation and focus in recent hospitality research", International Journal of Contemporary Hospitality Management, Vol. 23 No. 4, pp. 439-462.

Harrington, R.J., Chathoth, P.K., Ottenbacher, M. and Altinay, L. (2014), "Strategic management research in hospitality and tourism: past, present and future", International Journal of Contemporary Hospitality Management, Vol. 26 No. 5, pp. 778-808.

Hosseini, R.S., Zainal, A. and Sumarjan, N. (2015), "The effects of service performance of hotel customers on quality of experience and brand loyalty in Iran", Procedia-Social and Behavioral Sciences, Vol. 201, pp. 156-164.

IpKin, A.W. and Jennifer, H.G. (2014), "Exploring the direct and indirect effects of CSR on organizational commitment: the mediating role of corporate culture", International Journal of Contemporary Hospitality Management, Vol. 26 No. 4, pp. 500-525.

Irwin, A. (2002), Citizen Science: A Study of People, Expertise and Sustainable Development, Routledge.

Jauncey, S. and Nadkarni, S. (2014), "Expo 2020: what must Dubai's hospitality and tourism industry do to be ready pre-and post-event?", Worldwide Hospitality and Tourism Themes, Vol. 6 No. 4, pp. 381-386.

Jones, P., Hillier, D. and Comfort, D. (2016), "Sustainability in the hospitality industry: some personal reflections on corporate challenges and research agendas", International Journal of Contemporary Hospitality Management, Vol. 28 No. 1, pp. 36-67.

Kang, K.H., Lee, S. and Yoo, C. (2016), "The effect of national culture on corporate social responsibility in the hospitality industry", International Journal of Contemporary Hospitality Management, Vol. 28 No. 8, pp. 1728-1758.

Kodoatie, R.J. (2005), Introduction to infrastructure Management, Pustaka Pelajar, Yogyakarta.

Kusdi (2011), Organizational Culture: Theory, Research, and Practice, Penerbit Salemba Empatm, Jakarta.

Luckhurst, J. (1996), “Away game”, Marketing Week, 22 March, p. 41-5.

Malhotra, R. and Venkatesh, U. (2009), "Pre-crisis period planning: lessons for hospitality and tourism", Worldwide Hospitality and Tourism Themes, Vol. 1 No. 1, pp. 66-74.

Michael, B. and Goo, S.H. (2015), "Corporate governance and its reform in Hong Kong: a study in comparative corporate governance", Corporate Governance, Vol. 15 No. 4, pp. 444-475.

Murray, W.C., Elliot, S., Simmonds, K., Madeley, D. and Taller, M. (2017), "Human resource challenges in Canada's hospitality and tourism industry: finding innovative solutions", Worldwide Hospitality and Tourism Themes, Vol. 9 No. 4, pp. 391-401.

Musacchio, A. and Lazzarini, S.G. (2014), Reinventing State Capitalism, Harvard University Press, Massachusetts.

Ntongho, R.A. (2016), “Culture and corporate governance convergence”, International Journal of Law and Management, Vol. 58 No. 5, pp. 523-544.

Okumus, F., Altinay, L. and Roper, A. (2007), "Gaining access for research: reflections from experience", Annals of Tourism Research, Vol. 34 No. 1, pp. 7-26.

Pache, A.C. and Santos, F. (2013), "Inside the hybrid organization: selective coupling as a response to competing institutional logics", Academy of Management Journal, Vol. 56 No. 4, pp. 972-1001.

Parker, D. (2001), “The thrill seekers”, Marketing Week, September, 27, p. 67-9.

Parker, C. and Stone, B. (2003), Developing Management Skills for Leadership, Pearson Education, London.

Patterson, K.A. (2003), Servant Leadership: A Theoretical Model, Doctoral dissertation, Regent University.
Determinant of $\mathrm{CH}$ and corporate sustainability 
ITPD

4,2

124

Porras, J.I. and Silvers, R.C. (1991), "Organization development and transformation”, Annual Review of Psychology, Vol. 42 No. 1, pp. 51-78.

Purbawangsa, I.B.A., Solimun, S., Fernandes, A.A.R and Mangesti Rahayu, S. (2019), "Corporate governance, corporate profitability toward corporate social responsibility disclosure and corporate value (comparative study in Indonesia, China and India stock exchange in 20132016)", Social Responsibility Journal, Vol. 16 No. 7, pp. 983-999, doi: 10.1108/SRJ-08-2017-0160.

Rabbani, F., Hashmani, F.N., Mukhi, A.A.A., Gul, X., Pradhan, N., Hatcher, P., Farag, M. and Abbas, F. (2015), "Hospital management training for the Eastern Mediterranean Region: time for a change?", Journal of Health Organization and Management, Vol. 29 No. 7, pp. 965-972.

Ramsay, J. (1990), “Corporate hospitality: marketing of a monster?”, Management Decision, Vol. 28 No. 4, p. 20-2.

Rao, R.S. (2014), Emerging Trends in Hospitality and Tourism, Department of Basic Science and Humanities, Vignan`s Lara Institute of Technology and Science, Vol. 1.

Reino, S., Frew, A.J. and Albacete-Saéz, C. (2011), "ICT adoption and development: issues in rural accommodation", Journal of Hospitality and Tourism Technology, Vol. 2 No. 1, pp. 66-80.

Ruhanen, L., Scott, N., Ritchie, B. and Tkaczynski, A. (2010), "Governance: a review and synthesis of the literature", Tourism Review, Vol. 65 No. 4, pp. 4-16.

Salimath, M.S. and Jones, R. III (2011), "Population ecology theory: implications for sustainability", Management Decision, Vol. 49 No. 6, pp. 874-910.

Sanjeev, G.M. and Jauhari, V. (2012), "The emerging strategic and financial issues in the Indian hospitality industry: an overview", Worldwide Hospitality and Tourism Themes, Vol. 4 No. 5, pp. 403-409.

Searcy, C. (2011), "Updating corporate sustainability performance measurement systems", Measuring Business Excellence, Vol. 15 No. 2, pp. 44-56.

Sharma, M. (2016), Theoretical Foundations of Health Education and Health Promotion, Jones \& Bartlett Publishers, Massachussets.

Shleifer, A. and Vishny, R.W. (1997), "A survey of corporate governance", The Journal of Finance, Vol. 52 No. 2, pp. 737-783.

Sloan, P., Legrand, W. and Simons-Kaufmann, C. (2014), "A survey of social entrepreneurial communitybased hospitality and tourism initiatives in developing economies: a new business approach for industry", Worldwide Hospitality and Tourism Themes, Vol. 6 No. 1, pp. 51-61.

Sok, J., Blomme, R.J. and Tromp, D.M. (2014), "Relations between organizational culture and positive and negative work-home interference, and the mediating role of flexible work-home arrangements", British Journal of Management, Vol. 25 No. 3, pp. 456-472.

Solimun, Fernandes, A.A.R. and Nurjannah (2017), Multivariate Statistical Methods Structural Equation Modeling (SEM) Approach WarpPLS, UB Press, Malang.

Strobl, A. and Kronenberg, C. (2016), "Entrepreneurial networks across the business life cycle: the case of Alpine hospitality entrepreneurs", International Journal of Contemporary Hospitality Management, Vol. 28 No. 6, pp. 1177-1203.

Subagyo, S. (2008), “Time-driven activity-based costing”, Akuntansi Krida Wacana, Vol. 8 No. 3, pp. 223-234.

Thatcher, M. (2000), “Going places”, Marketing Business, April, pp. 42-44.

Tricker, R. (2012), ISO 9001: 2000 for Small Businesses, Routledge.

Tromp, D.M. and Blomme, R.J. (2014), "Leadership style and negative work-home interference in the hospitality industry", International Journal of Contemporary Hospitality Management, Vol. 26 No. 1, pp. 85-106. 
Tsang, N.K., Lee, L.Y.S. and Qu, H. (2015), "Service quality research on China's hospitality and tourism industry", International Journal of Contemporary Hospitality Management, Vol. 27 No. 3, pp. 473-497.

Umar, M.B. (2005), "Legal issues in the management of Nigeria's production sharing contracts from a study of the Nigerian national petroleum corporation's (national petroleum management services') perspective”, Oil, Gas and Energy Law Journal (OGEL), Vol. 3 No. 1, pp. 1-120.

Vera, D. and Crossan, M. (2004), "Strategic leadership and organizational learning", Academy of Management Review, Vol. 29 No. 2, pp. 222-240.

Yeoman, I., Schanzel, H. and Smith, K. (2013), "A sclerosis of demography: how ageing populations lead to the incremental decline of New Zealand tourism”, Journal of Vacation Marketing, Vol. 19 No. 2, pp. 91-103.

Zakaria, I., Rahman, B.A., Othman, A.K., Yunus, N.A.M., Dzulkipli, M.R. and Osman, M.A.F. (2014), "The relationship between loyalty program, customer satisfaction and customer loyalty in retail industry: a case study", Procedia-Social and Behavioral Sciences, Vol. 129, pp. 23-30.

\section{Corresponding author}

Hamidah Nayati Utami can be contacted at: hamidah.ub.fia@gmail.com
Determinant of $\mathrm{CH}$ and corporate sustainability 